\title{
GASTRIC HELICOBACTER SPP. INFECTION IN CAPTIVE NEOTROPICAL BRAZILIAN FELINE
}

\author{
Pedro Luiz de Camargo ${ }^{1}$, Simone Akemi Uenaka ${ }^{1}$, Maitê Bette Motta ${ }^{1}$, Cristina Harumi Adania ${ }^{2}$, Letícia Yamasaki ${ }^{3}$, \\ Amauri A. Alfieri ${ }^{3}$, Ana Paula F. R. L. Bracarense ${ }^{3 *}$ \\ ${ }^{1}$ Departamento de Clínicas Veterinárias, Universidade Estadual de Londrina, Londrina, PR, Brasil; ${ }^{2}$ Centro Brasileiro para \\ Conservação de Felinos Neotropicais, Associação Mata Ciliar, Jundiaí, SP, Brasil; ${ }^{3}$ Departamento de Medicina Veterinária \\ Preventiva, Universidade Estadual de Londrina, Londrina, PR, Brasil.
}

Submitted: March 15, 2010; Returned to authors for corrections: April 26, 2010; Approved: June 21, 2010.

\begin{abstract}
Ten captive neotropical Brazilian feline were submitted to gastroscopic examination and samples of gastric mucosa from fundus, corpus and pyloric antrum were evaluated for the presence of Helicobacter species. Warthin-Starry (WS) staining and PCR assay with species-specific primers and enzymatic cleavage were applied for bacterial detection and identification. Histological lesions were evaluated by haematoxylin and eosin staining. All animals showed normal gross aspect of gastric mucosa. Helicobacter heilmannii was confirmed in $100 \%$ of the samples by WS and PCR assay. Mild lymphocytic infiltrate in the lamina propria was observed in eight animals, mainly in the fundus region. Small lymphoid follicles were seen in three animals. No significant association between Helicobacter infection and histological findings was verified. These observations suggest that gastric Helicobacter spp. could be a commensal or a eventual pathogen to captive neotropical feline, and that procedures, way life, and stress level on the shelter apparently had no negative repercussion over the integrity of the stomach.
\end{abstract}

Key words: Helicobacter, feline, gastric diseases, PCR, Leopardus.

\section{INTRODUCTION}

Helicobacter pylori infection in human beings has been associated with gastritis, gastric and duodenal ulcer, gastric adenocarcinoma, and MALT (mucosa associated-lymphoid tissue) lymphoma. While $H$. pylori is accepted as the dominant human gastric bacterial pathogen, a small percentage of human infections have been associated with $H$. heilmannii, which is more prevalent in pet and wild animals (3). The high prevalence of this species in animals has been suggested to have implication for public health (5). However, the subtypes of $H$. heilmannii strain that colonizes humans and animals are different, indicating that animals represent a lower risk to man (17).

In several studies gastritis was associated with Helicobacter spp. infection in tigers, lions and cheetahs. Helicobacter acinonyx was implicated in gastritis in tigers (19). In a retrospective survey conducted with 69 captive cheetahs, $40 \%$ of the deaths were associated with severe gastritis induced by Helicobacter spp. infection (13). Moreover, the infection was also associated with gastroduodenal adenocarcinoma and rectal adenoma in a

*Corresponding Author. Mailing address: Campus Universitário, 86051-990, Londrina, Paraná, Brazil.; Tel.: 5543 33714766 Fax: 5543 33714485.; Email address: anapaula@uel.br 
cougar (25). By contrast, others researches found no association between infection and gastric mucosal inflammatory infiltrate, suggesting that the bacteria are commensal or opportunist pathogens $(7,23)$. Also, the study of 28 semi captive cheetahs found out mild or no lesions in 27 , concluding that gastritis was uncommon in these animals and proposing that stress could play a major role in the development of Helicobacter-associated gastritis (12).

In captive wild feline animals stress and host factors might be important issues in the development of gastritis associated with Helicobacter infection (23). The presence of Helicobacter spp. in the stomach of wild or captive feline has been reported in several countries $(6,10,13)$; however the relationship between infection and gastric diseases remains controversial. Gross and histological analysis, and molecular characterization of Helicobacter species in captive neotropical Brazilian feline have not been previously described. Therefore, the purpose of the current report was to examine the presence of Helicobacter in gastric mucosa, and evaluate the association between infection, gross and histological findings in neotropical Felidae.

\section{MATERIALS AND METHODS}

\section{Specimens}

Samples of gastric mucosa from four female little spotted cat (Leopardus tigrinus), five female ocelots (Leopardus pardalis), and one male cougar (Puma concolor) were evaluated. The animals were housed at Brazilian Center to Conservation of Neotropical Feline - Mata Ciliar Association, São Paulo, southern Brazil. None of the feline had any previous signs of gastric disease. The animals were fed with fresh meet of chicken, cattle, and viscera. The study was approved by the institutional Ethics Committee for Animal Experimentation.

Food and water were withheld for $12 \mathrm{~h}$ before gastroscopy and gastric biopsy. The animals were anaesthetized with xylazine $(1 \mathrm{mg} / \mathrm{kg}, \underline{\mathrm{im}})$ and ketamine $(10 \mathrm{mg} / \mathrm{Kg}, \underline{\mathrm{im}})$. The biopsy procedure was performed with a flexible paediatric endoscope (2.3 mm diameter biopsy) and two samples of gastric mucosa from pyloric antrum, corpus and fundus were collected. The mucosal aspect, presence of content, friability and bleeding at biopsy were evaluated at gastroscopy.

Gastric samples were fixed in Bouin's solution for $24 \mathrm{~h}$, embedded in paraffin wax and processed routinely. Sections (3 $\mu \mathrm{m})$ were stained with haematoxylin and eosin (HE) and Warthin-Starry (WS) method for histological evaluation and Helicobacter detection, respectively. For molecular analysis a further sample from each gastric region was placed into a tube DNase and RNase-free and frozen at $-20^{\circ} \mathrm{C}$ until DNA extraction.

\section{Histological analysis}

Location and colonization density of Helicobacter were assessed. Colonization density was scored based in the number of bacteria per field (1000x magnification) as 0 (no infection); 1 ( 1 to 10 bacteria per field); 2 (11 to 30 ); 3 (31 to 50 ); and 4 (more than 50 bacteria). Histological changes were evaluated and scored as described elsewhere (20). Briefly, the number of lymphoid aggregates, the number of inflammatory cells and epithelial changes were evaluated. Gastritis was diagnosed when more then four inflammatory cells per field in the lamina propria were observed.

\section{Polymerase Chain Reaction}

Gastric biopsies were digested with $25 \mu$ l proteinase K (20 $\mathrm{mg} / \mathrm{ml})$ in $200 \mu \mathrm{l}$ of lysis buffer pH $8.0(100 \mathrm{mM} \mathrm{NaCl}, 100$ mM EDTA, and $0.5 \%$ dodecyl sodium sulphate), agitated for $30 \mathrm{sec}$ and then incubated at $56^{\circ} \mathrm{C}$ for $3 \mathrm{~h}$. The DNA was extracted with a combination of phenol/chloroform/isoamyl alcohol and silica/guanidinium isothiocyanate methods as described by Alfieri et al. (1). Sterile ultrapure water was included as negative control in all DNA extraction.

The genes targeted for Helicobacter genus and Helicobacter species, the primer sequences, the annealing temperatures, and the size (base pairs) of amplified fragments were described in a previous study (2). All gastric samples were tested for the species H. pylori, H. heilmannii, H. felis, and $H$. bizzozeronii or $H$. salomonis. PCR assay was 
performed in a final volume of $25 \mu \mathrm{l}$ containing $1 \mu \mathrm{l}$ of extracted DNA, $0.4 \mathrm{mM}$ of each deoxynucleotide, $0.5 \mu \mathrm{l}$ (20 pmol) of each primer, $1 \times$ PCR buffer (20 mM Tris $\mathrm{HCl} \mathrm{pH} 8.4$ and $50 \mathrm{mM} \mathrm{KCl}$ ), $1.5 \mathrm{mM} \mathrm{MgCl}_{2}, 1.25 \mathrm{U}$ Platinum Taq DNA polymerase (Invitrogen ${ }^{\mathrm{TM}}$ Life Technologies, USA), and ultrapure water. A negative control was included in every amplification reaction. Amplifications were performed in a PTC-100 ${ }^{\mathrm{TM}}$ thermocycler (MJ Research Inc, USA). The enzymes VspI (7) and Hinf I (4) (Life Technologies ${ }^{\circledR}$ ) were applied in the material amplified with specific pair primers, and the enzyme Hinf $\mathrm{I}$ in the species specific primers. Seventeen microliters from amplified material were added to $2 \mu \mathrm{l}$ of specific buffer and $1 \mu \mathrm{l}$ of enzyme, and maintained at $37^{\circ} \mathrm{C}$ for $1 \mathrm{hr}$. Products from PCR and from enzymatic cleavage were analyzed by electrophoresis in $2 \%$ agarose gel with ethidium bromide in Tris-Borate-EDTA (TBE) buffer and visualized under UV light. The expected lengths products from enzymatic cleavage were disposed in Table 1.

Table 1. Species and expected length (in base pairs) from fragments according to the enzyme employed.

\begin{tabular}{ccc}
\hline Species & Enzyme* $^{*}$ & Expected length fragments \\
\hline Helicobacter spp. & Hinf I & 254 and $145 \mathrm{pb}$ \\
& Vsp I & 295 and $104 \mathrm{pb}$ \\
H. heimannii & Hinf I & 408 and $172 \mathrm{pb}$ \\
\hline
\end{tabular}

* Invitrogen Life Technologies ${ }^{\circledR}$

\section{Statistical Analysis}

The association between colonization density, inflammatory infiltrate and Helicobacter infection in the gastric regions was evaluated by the Kruskal-Wallis test. The Spearman test was performed to verify the correlation between colonization density and inflammation (18). Significance was set at $\mathrm{p}<0.05$.

\section{RESULTS}

All animals showed a normal macroscopic aspect of esophagus mucosa, except in one Leopardus tigrinus that had no herring bone pattern at the distal segment of the esophagus. In three animals small patches of mucosal erythema and bilious fluid were observed in gastric mucosa. Plant fragments and hair coat were seen in the stomach of all animals.

Tightly coiled bacteria, 5 to $12 \mu \mathrm{m}$ long, were detected in $100 \%$ of the samples stained by WS method (Figure 1). The bacteria were seen isolate or in clusters in superficial mucus layer and gastric pits. Scores of bacterial colonization ranged from 1 to 4 (Table 2). Although scores 3 and 4 were more frequently observed in the corpus region, there was no significant difference in colonization density between the gastric regions $(\mathrm{p}=0.54)$.

Histological evaluation showed mild lymphocytic infiltrate in fundus. Inflammatory infiltrate is significantly higher in this region than in corpus and pyloric antrum $(\mathrm{p}<0.001)$. Two animals showed no inflammatory cells in gastric mucosa even with high colonization density (Table 2). No association was found between bacterial colonization and mucosal inflammation $(\mathrm{p}=0.330)$. Epithelial alterations were rarely seen and when present were sparse and mild in magnitude.

In three animals lymphoid follicles were observed in the lamina propria. The lymphocyte aggregates appeared small and fewer reactive. No more than one lymphoid follicle per sample was observed. The frequency and distribution of lymphoid follicles are summarized in Table 2.

Samples from all animals generated a 399 bp amplicon with Helicobacter genus reaction. Cleavage of the amplified products by genus specific primer (399 bp) using Hinf I and Vsp I enzymes resulted in fragments with 254 and 145 bp, and 
with 295 and 104 bp in length, respectively (Figure 2). The reactions with species specific primers were positive only for $H$. heilmannii, represented by a $580 \mathrm{pb}$ amplicon. Cleavage of
H. heilmannii amplicon with Hinf I enzyme resulted in fragments with 408 and 172 bp in length (Figure 3). No mixed infection was detected.

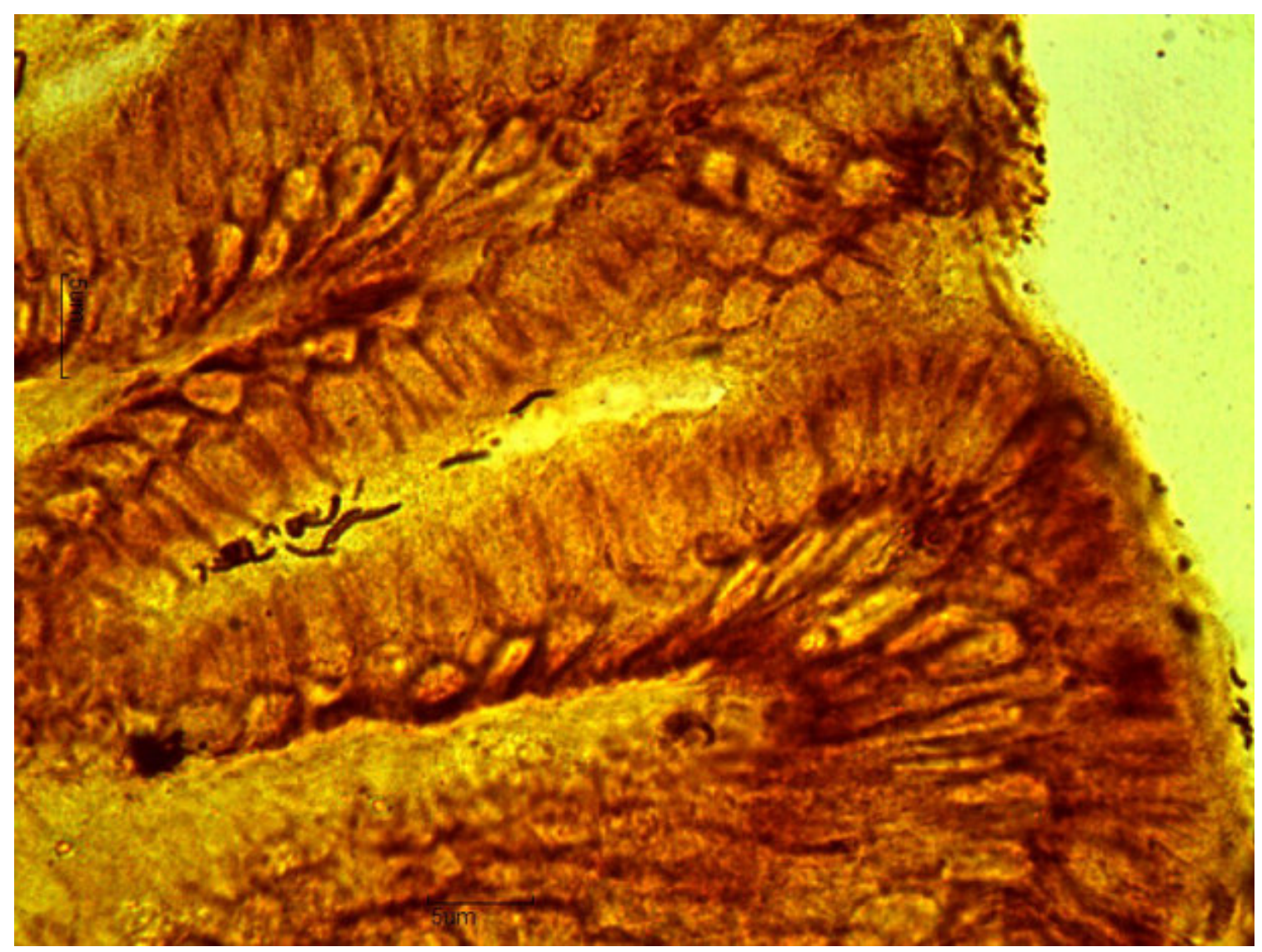

Figure 1. The gastric mucosa of a Leopardus tigrinus. H. heilmannii colonizing gastric pits. Warthin-Starry staining. Bar, $5 \mu$ m.

Table 2. Scores of bacterial colonization and cellular inflammatory infiltrate observed in gastric mucosa samples of captive neotropical Brazilian feline.

\begin{tabular}{|c|c|c|c|c|c|c|c|}
\hline \multirow{3}{*}{ Species } & \multirow{3}{*}{ Animal } & \multicolumn{6}{|c|}{ Bacterial and inflammatory cell infiltrate scores in gastric regions } \\
\hline & & \multicolumn{2}{|c|}{ Fundus } & \multicolumn{2}{|c|}{ Corpus } & \multicolumn{2}{|c|}{ Pyloric antrum } \\
\hline & & Bacterial & Cell infiltrate & Bacterial & Cell infiltrate & Bacterial & Cell infiltrate \\
\hline \multirow[t]{4}{*}{ Leopardus tigrinus } & 01 & $3^{*}$ & 1 & 4 & 0 & 2 & 0 \\
\hline & 02 & 2 & 1 & 3 & 0 & 2 & 1 \\
\hline & 03 & 2 & 1 & 3 & 0 & 4 & 0 \\
\hline & 04 & $3 *$ & 1 & $3 *$ & 0 & 3 & 0 \\
\hline \multirow[t]{5}{*}{ Leopardus pardalis } & 05 & 4 & 0 & 3 & 0 & 4 & 0 \\
\hline & 06 & 1 & 0 & 4 & 0 & 1 & 0 \\
\hline & 07 & 2 & 1 & 2 & 0 & 2 & 0 \\
\hline & 08 & 3 & 1 & $2 *$ & 0 & 2 & 0 \\
\hline & 09 & 2 & 1 & 2 & 0 & 3 & 0 \\
\hline Puma concolor & 10 & 2 & 1 & 2 & 0 & 2 & 0 \\
\hline
\end{tabular}




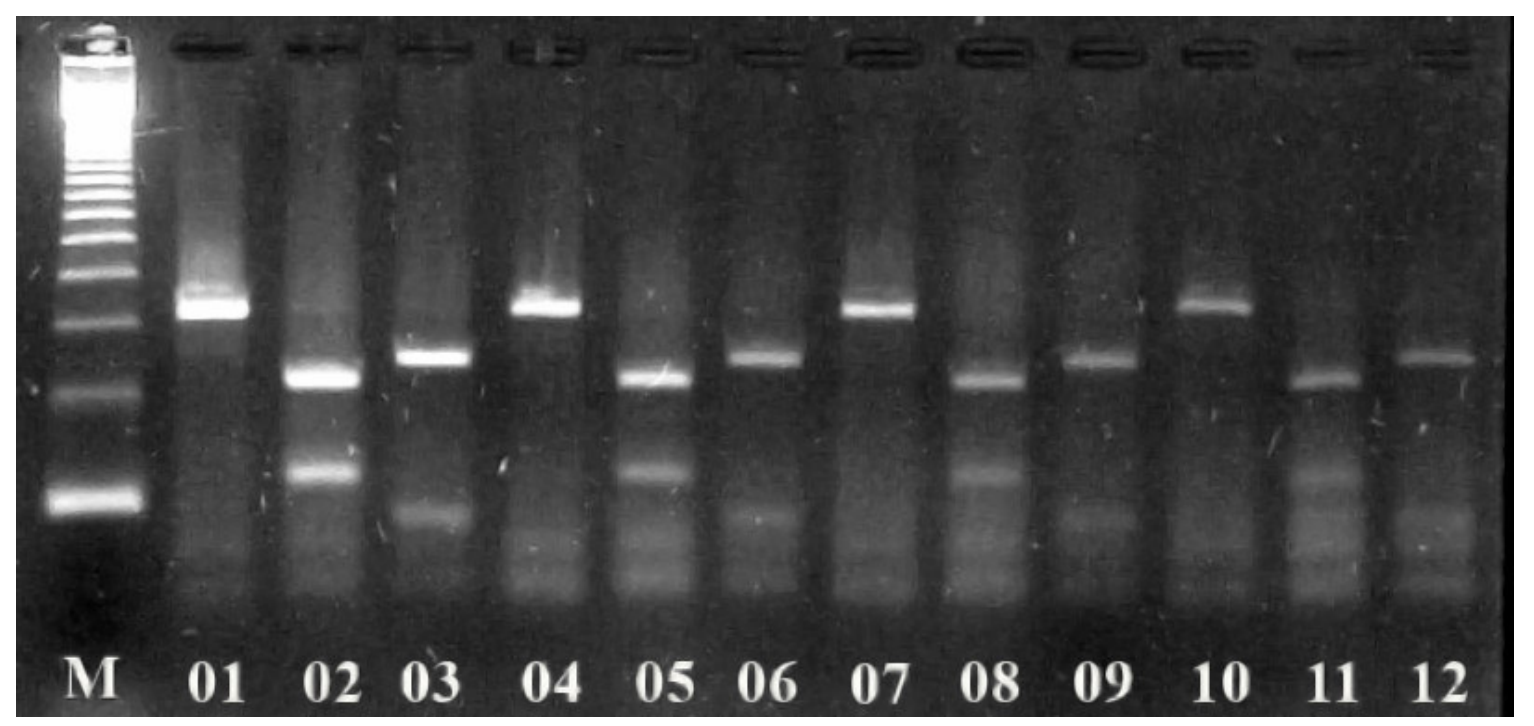

Figure 2. Ethidium bromide stained $2 \%$ agarose gel electrophoresis of restriction fragment length polymorphism (RFLP) with Hinf I and Vsp I enzymes of Helicobacter spp. genus amplicons. Lane M: 123 bp ladder (Invitrogen Life Technologies, USA); Lanes 1, 4, 7, and 10: Helicobacter spp. genus amplicons (399 bp) from captive neotropical Brazilian feline gastric mucosal samples; Lanes 2, 5, 8, and 11: Helicobacter spp. genus amplicons digested with Hinf I (254 and 145 bp). Lanes 3, 6, 9, and 12: Helicobacter spp. genus amplicons digested with Vsp I (295 and 104 bp).

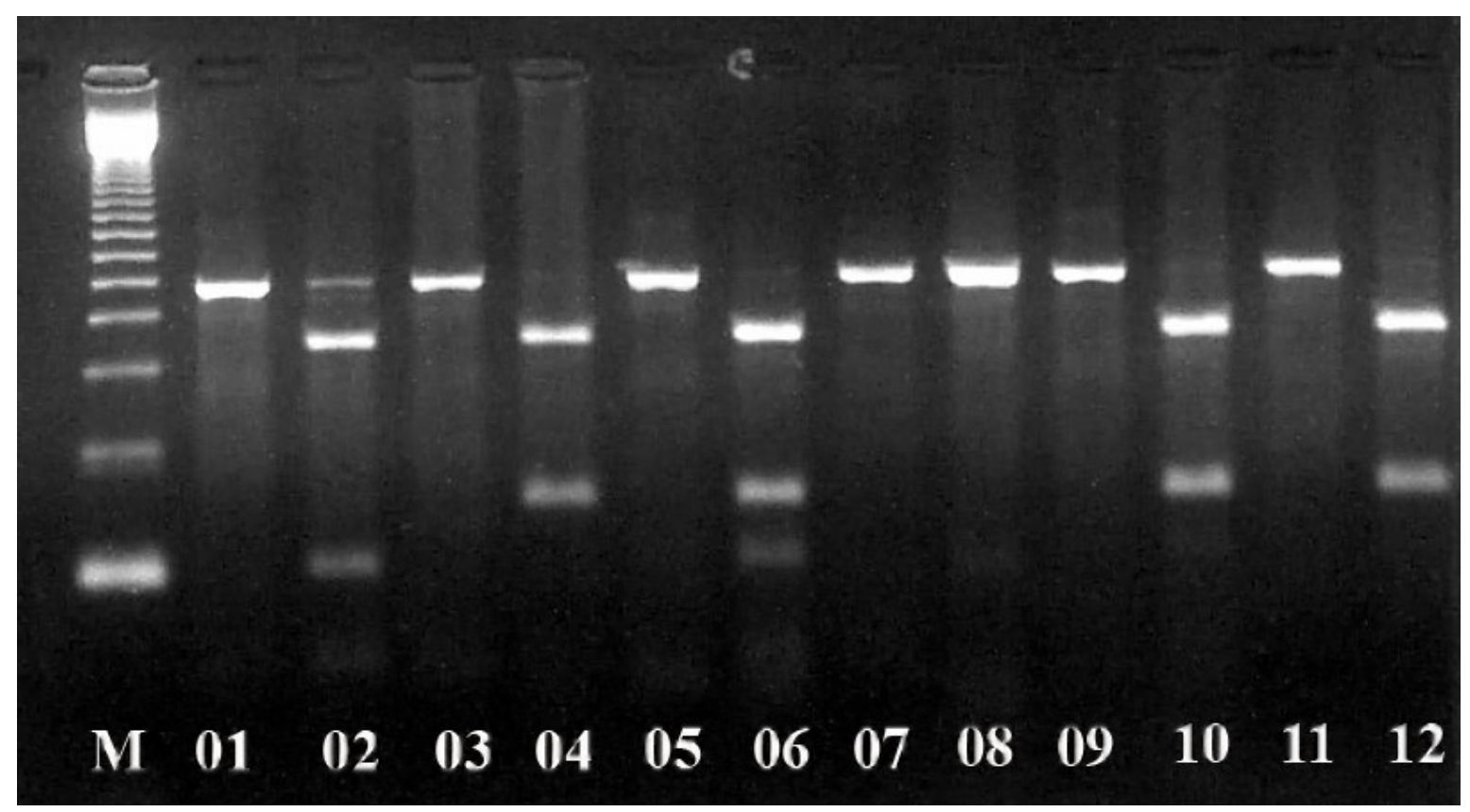

Figure 3. Ethidium bromide stained $2 \%$ agarose gel electrophoresis of restriction fragment length polymorphism (RFLP) with Hinf I enzyme of Helicobacter heimannii amplicons. Lane M: 123 bp ladder (Invitrogen Life Technologies, USA); Lanes 1, 3, 5, 7, 9, and 11: H. heilmannii amplicons (580 bp) from captive neotropical Brazilian feline gastric mucosal samples; Lanes 2, 4, 6, 8, 10, and 12: RFLP of H. heilmannii amplicons digested with Hinf I (408 and $172 \mathrm{bp}$ ). 


\section{DISCUSSION}

No previous studies of gastric endoscopic pattern in Brazilian neotropical feline were reported. The findings were compared to the patterns registered for domestic cats. On the endoscopic evaluation the most unexpected alteration was the absence of transversal rings observed upon distal esophagus in an adult Leopardus tigrinus. Others animals of the same species that were evaluated, showed a herring bone pattern. This pattern is typically seen in domestic cats, and is expected in Felidae family (21). The ingestion of grass and plants is considered a normal pattern between feline, and bilious reflux probably is related to pyloric relaxation mediate by anesthetic drugs (22). Mucosal erythema could be seen in domestic cats and dogs as a result of local blood flow variations in physiologic conditions (8). The endoscopic aspects observed were not associated with gastric disease, as animals presented normal behavior and activity level, good nutritional status and showed no alterations on physical examination. Furthermore, the feline had no previous signs of gastric disease, such as weight loss, variable appetite or vomit.

This study had characterized that Brazilian neotropical captive feline were commonly infected by Helicobacter, as free-ranging and captive cheetahs from South Africa and North America (14). Gastritis accompanied by vomit and weight loss was reported as a major cause of death in captive cheetahs, meanwhile the association with Helicobacter infection still controversial (23). Differently from cheetahs, captive Leopardus tigrinus, L. pardalis and Puma color showed no signs of gastric disease, supporting the hypotheses of commensal bacteria in these species.

In none mucosal sample bacteria resembling $H$. pylori or $H$. acinonyx were observed as previously reported $(6,19,24)$. The bacterial morphology and distribution on the mucosa was similar to previously observed in Brazilian pet cats (20). The results of PCR and enzymatic cleavage confirmed the infection by $H$. heilmannii which was the most frequent species detected in cheetahs (23) and cats (16). Nevertheless, to the best of the authors' knowledge, this report represents the first cases of
Helicobacter infection in captive neotropical feline confirmed by PCR assay in Brazil.

Gastritis has been associated with Helicobacter infection in a variety of wild carnivores $(9,10)$. In the present study, mild lymphocytic infiltrate was frequently observed, mainly in the corpus region. However, no association between colonization density and the degree of inflammation was verified. Furthermore, mucosal samples with no sign of inflammation were taken from two infected animals. It has been suggested that gastric pathology develops when the bacteria acquire characteristics such as the cag pathogenicity island. The $\operatorname{cag} A$ gene is a marker for virulence factors in $H$. pylori, inducing a neutrophilic inflammation (15), however this genomic region was not identified in samples from cheetahs with gastritis (23). Although it is possible that other pathogenicity factors could be involved in Helicobacter spp. gastritis, it is more likely that $H$. Heilmannii in captive neotropical feline are commensals or opportunistic organisms.

The presence of lymphoid aggregates was reported as the main histological change associated with the Helicobacter spp. infection in semi or captive feline $(10,19)$. However, in our study small lymphoid follicles were seen in three animals, despite the presence of Helicobacter in all samples. These structures are normally seen on gastrointestinal tract, increasing in number and dimension in response to antigenic stimulation. Thus, apparently no relationship exists between the presence of bacteria and inflammatory infiltrate or lymphoid aggregates in wild feline.

Extrinsic factors, stress and genetic impoverishment had an important role in the pathogenesis of gastritis (23). The fact that captive feline had a greater occurrence of gastritis than wild animals (14) strengthen the effect of stress in this lesion. Our results had demonstrated that, differently from captive cheetahs, captive feline from the Atlantic Forest (São Paulo, Brazil) had no significant gastritis. Differences in conservation management and adaptability to environmental changes could explain the absence of gastric disease in this captive population.

In conclusion, the present study shows that captive 
neotropical Brazilian feline are commonly infected by $H$. heilmannii. The infection was not associated with clinical signs, gross or histological changes, suggesting that these gastric bacteria are just commensals or occasional pathogens. Also, the practices employed to maintain the animals seem adequate to minimize stressful conditions, contributing to gastric mucosal homeostasis.

\section{ACKNOWLEDGMENTS}

The authors wish to thank CNPq-Brazil for awarding a research fellowship to A.P.F.R.L. Bracarense and A.A. Alfieri.

\section{REFERENCES}

1. Alfieri, A.A.; Parazzi, M.E.; Takiuchi, E.; Médici, K.C.; Alfieri, A.F. (2006). Frequency of group A rotavirus in diarrhoeic calves in Brazilian cattle herds, 1998-2002. Trop. Anim. Health Prod. 38, 521-526.

2. Camargo, P.L.; Alfieri, A.A.; Bracarense, A.P.F.R.; Menoli, R.; Spinosa, S.R.; Hagiwara, M.K. (2003). Use of polymerase chain reaction and enzymatic cleavage in the identification of Helicobacter spp. in gastric mucosa of human beings from North Paraná, Brazil. Mem. Inst. Oswaldo Cruz 98, 265-268.

3. Cattoli, G.; Bart, A.; Klaver, P.S.; Robijn, R.J.; Beumer, H.J.; Van Vugt, R.; Pot, R.G.; Van der Gaag, I.; Vanderbroucke-Grauls, C.M.; Kuipers, E.J.; Kusters, J.G. (2000). Helicobacter acinonychis eradication leading to the resolution of gastric lesions in tigers. Vet. Rec. 147, 164-165.

4. Clayton, C.L.; Kleanthous, H.; Coates, P.J.; Morgan, D.D.; Tabaqchali, S. (1992). Sensitive detection of Helicobacter pylori by using polymerase chain reaction. J. Clin. Microbiol. 30, 192-200.

5. Dieterich, C.; Wiesel, P.; Neiger, R.; Blum, A.; Corthesy-Theulaz, I. (1998). Presence of multiple "Helicobacter heilmanni" strains in an individual suffering from ulcers and in his two cats. J. Clin. Microbiol. 36, 1366-1370.

6. Eaton, K.A.; Radin, M.J.; Kramer, L.; Wack, R.; Sherding, R.; Krakowka, S.; Fox, J. G.; Morgan, D.R. (1993). Epizootic gastritis associated with gastric spiral bacilli in cheetahs (Acinonyx jubatus). Vet. Pathol. 30, 55-63.

7. Germani, Y.; Dauga, C.; Duval, P.; Huerre, M.; Levy, M.; Pialoux, G.; Sansonetti, P.; Grimont, P.A. (1997). Strategy for the detection of Helicobacter species by amplification of 16S rRNA genes and identification of H. felis in a human gastric biopsy. Res. Microbiol. 148, 315-326.

8. Guilford, W.G. (2005). Upper Gastrointestinal Endoscopy. In: McCarthy, T.C. (ed). Veterinary Endoscopy for the Small Animal Practioner.
Elsevier Saunders, Missouri, USA, p.279-321.

9. Hill, J.E.; Khanolkar, S.S.; Stadtländer, C.T.K.H. (1997). Gastric ulcer associated with a Helicobacter-like organism in a cougar (Felis concolor). Vet. Pathol. 34, 50-51.

10. Jakob, W.; Stolte, M.; Valentin, A.; Schröder, H.D. (1997). Demonstration of Helicobacter pylori-like organisms in the gastric mucosa of captive exotic carnivores. J. Comp. Pathol. 116, 21-33.

11. Kinsel, M.J.; Briggs, M.B.; Venzke, K.; Forge, O.; Murnane, R.D. (1998). Gastric spiral bacteria and intramuscular sarcocysts in African lions from Namibia. J. Wildl. Dis. 34, 317-324.

12. Lobetti, R.; Picard, J.; Kriek, N.; Rogers, P. (1999). Prevalence of helicobacteriosis and gastritis in semicaptive cheetahs (Acinonyx jubatus). J. Zoo Wildl. Med. 30, 492-496.

13. 13 Munson, L.; Nesbit, J.W.; Meltzer, D.G.; Colly, L.P.; Bolton, L.; Kriek, N.P. (1999). Diseases of captive cheetahs (Acinonyx jubatus jubatus) in South Africa: a 20-year retrospective survey. J. Zoo Wildl. Med. 30, 342-347.

14. Munson, L.; Terio, K.; Werley, M.; Jago, M.; Bagot-Smith, A.; Marker, L. (2005). Extrinsic factors significantly affect patterns of disease in freeranging and captive cheetah (Acinonyx jubatus) populations. J. Wildl. Dis. 41, 542-548.

15. Nilsson, C.; Sillén, A.; Eriksson, L.; Strand, M.L.; Enroth, H.; Normark, S.; Falk, P.; Engstrand, L. (2003). Correlation between cag Pathogenicity Island composition and Helicobacter pylori-associated gastroduodenal disease. Infect. Immun. 71, 6573-6581.

16. Norris, C.R.; Marks, S.L.; Eaton, K.A.; Torabian, S.Z.; Munn, R.J.; Solnick, J.V. (1999). Healthy cats are commonly colonized with "Helicobacter heilmannii" that is associated with minimal gastritis. $J$. Clin. Microbiol. 37, 189-194.

17. Priestnall, S.L.; Wiinberg, B.; Spohr, A.; Neuhaus, B.; Kuffer, M.; Wiedmann, M.; Simpson, K.W. (2004). Evaluation of "Helicobacter heilmannii" subtypes in the gastric mucosas of cats and dogs. J Clin Microbiol. 42, 2144-2151.

18. Shot, S. (1990). Statistics for health professionals. WB Saunders, Philadelphia.

19. Schröder, H.D.; Ludwig, C.; Jakob, W.; Reischl, U.; Stolte, M.; Lehn, N. (1998). Chronic gastritis in tigers associated with Helicobacter acinonyx. J. Comp. Pathol. 119, 67-73.

20. Takemura, L.S.; Camargo, P.L.; Alfieri, A.A.; Bracarense, A.P.F.R.L. (2009). Helicobacter spp. in cats: association of infecting species and epithelial proliferation within the gastric lamina propria. J. Comp. Pathol. 141, 127-134.

21. Tams, R.T. (1999). Small animal endoscopy. Mosby Company, St. Louis.

22. Tams, R.T. (2003). Handbook of Small Animal Gastroenterology. Saunders Company, St. Louis.

23. Terio, K.A.; Munson, L.; Marker, L.; Aldridge, B.M.; Solnick, J.V. (2005). Comparison of Helicobacter spp. in cheetahs (Acinonyx jubatus) with and without gastritis. J. Clin. Microbiol. 43, 229-234. 
24. Wack, R.F.; Eaton, D.A.; Kramer, L.W. (1997). Treatment of gastritis in cheetahs (Acinonyx jubatus). J. Zoo Wildl. Med. 28, 260-266.

25. Yamazaki, Y.; Aono, I.; Ohya, T.; Shibahara, T. Kadota, K. (2002).
Gastroduodenal adenocarcinomas and rectal adenoma in a cougar (Felis concolor) infected with Helicobacter-like organisms and spirochetes. $J$. Vet. Med. Sci. 64,149-153. 